\title{
Inventory of Ferns and Lycophytes of the RPPN Pedra D'Antas, Pernambuco state, northeastern Brazil
}

\author{
Rafael Farias $^{l^{*}}$, Ivo Silva ${ }^{2}$, Anna Flora Pereira ${ }^{3}$, Augusto Santiago ${ }^{4}$ \& Iva Barros ${ }^{1}$ \\ ${ }^{1}$ Universidade Federal de Pernambuco, Recife, PE, Brazil \\ ${ }^{2}$ Universidade Federal Rural do Rio de Janeiro, Seropédica, RJ, Brazil \\ ${ }^{3}$ Universidade Federal do Vale do São Francisco, São Raimundo Nonato, PI, Brazil \\ ${ }^{4}$ Universidade Federal de Pernambuco, Vitória de Santo Antão, PE, Brazil \\ "Corresponding author: Rafael Farias, e-mail: rafaelpfarias@hotmail.com
}

FARIAS, R., SILVA, I., PEREIRA, A. F., SANTIAGO, A., BARROS, I. Inventory of Ferns and Lycophytes of the RPPN Pedra D'Antas, Pernambuco state, northeastern Brazil. Biota Neotropica. 17(4): e20170364. http://dx.doi. org/10.1590/1676-0611-BN-2017-0364

\begin{abstract}
The Northeastern Atlantic Forest (NAF) has a historic of intense habitat loss and fragmentation. In this context, knowledge of the species from forest remnants is urgently needed and represents a key tool for future studies and conservation strategies. Here, we present the floristic inventory of ferns and lycophytes from the Private Natural Heritage Reserve - RPPN Pedra D'Antas, located in a NAF area. The study area associated with the RPPN Frei Caneca is the Serra do Urubu, which is a hotspot for the diversity of several biological groups in the NAF. We recorded 74 fern species, distributed in 17 families and 46 genera. The most diverse families were Pteridaceae (17 species), Polypodiaceae (14 spp.), Dryopteridaceae (nine spp.) and Thelypteridaceae (seven spp.). Lycophytes were represented by four species, two families and two genera. A new record for the Northeast of Brazil, Serpocaulon hirsutulum, is presented in this study. The area has a large number of species, some of which are restricted to the NAF (e.g. Megalastrum umbrinum). Based on the richness of the study area associated with another inventory held at the RPPN Frei Caneca (138 spp.), the Serra do Urubu is corroborated as a hot-spot for the diversity of ferns and lycophytes in the NAF.
\end{abstract}

Keywords: Atlantic Forest, biodiversity, conservation, floristic survey, seedless vascular plants

\section{Inventário de Samambaias e Licófitas da RPPN Pedra D’Antas, estado de Pernambuco, nordeste do Brasil}

Resumo: A Floresta Atlântica Nordestina (FAN) possui um histórico de intensa perda e fragmentação de hábitats. Neste contexto, o conhecimento das espécies a partir das áreas ainda remanescentes é urgentemente requerido, constituindo a ferramenta básica para estudos futuros e estratégias conservacionistas. Aqui, apresentamos o inventário de samambaias e licófitas a partir da Reserva Particular do Patrimônio Natural - RPPN Pedra D'Antas, situada em área da FAN. A área de estudo associada a RPPN Frei Caneca constitui a Serra do Urubu, conhecida como um hot-spots de diversidade para diversos grupos biológicos na FAN. Registramos 74 espécies de samambaias, distribuídas em 17 famílias e 46 gêneros. As famílias mais diversas foram Pteridaceae (17 espécies), Polypodiaceae (14 spp.), Dryopteridaceae (nove spp.) e Thelypteridaceae (sete spp.). As licófitas foram representadas por quarto espécies, duas famílias e dois gêneros. Apresentamos um novo registro para o Nordeste brasileiro, Serpocaulon hirsutulum. A área possui um número expressivo de espécies, algumas das quais com destruição restrita a FAN (e.g. Megalastrum umbrinum). A partir da riqueza da área de estudo associada a outro inventário realizado na RPPN Frei Caneca (138 spp.), corroboramos a Serra do Urubu como um hot-spot de diversidade para as samambaias e licófitas na FAN.

Palavras-chave: Floresta Atlântica, biodiversidade, conservação, levantamento florístico, plantas vasculares sem sementes

\section{Introduction}

The number of floristic inventories for the various ecosystems of the Brazilian territory has grown in recent decades, as evidenced by the Forzza et al. 2010. However, thorough knowledge of the high plant diversity occurring in the country, which is highly threatened by many anthropogenic pressures, still requires more efforts. Inventories are the means by which such knowledge is achieved (Magurran 2004). They allow recognizing the areas that hold highest richness as well as update the floras and biogeographical patterns of distribution of species (e.g. new records of species and/or species with restricted distribution), which represents key information for several biological studies and future conservation strategies (see Prado \& Hirai 2011, Gasper et al. 2012), identifying forest remnants most important to conservation on a given geographic or politic scale.

The need for more inventories is stressed by the excessive loss of species caused by intense levels of degradation in Brazilian ecosystems. It is likely that some species may disappear even before registration at 
local, regional or national level. Particularly, the Northeastern Atlantic Forest (NAF) in Brazil (region north of the São Francisco River, covering the States of Alagoas, Pernambuco, Paraíba, Rio Grande do Norte, and enclaves in Ceará State) has a notorious scenario of intense habitat loss and fragmentation resulting from a long historical period of disturbances. Furthermore, few protected areas have been established in this biogeographical unit, which is recognized by its high vulnerability and loss of species (Tabarelli et al. 2006, Ribeiro et al. 2009).

The Serra do Urubu comprises two protected areas: the Private Natural Heritage Reserve (Reserva Particular do Patrimônio Nacional - RPPN) Frei Caneca and the RPPN Pedra D'Antas, and represents one of the last largest forest NAF remnants, with approximately 1000 ha. This area has high species richness and endemism, being considered a hotspot for biodiversity of flowering plants in the NAF (Melo et al. 2016), and one of the most important areas for bird conservation in the Neotropics (SAVE Brasil 2016). Moreover, the RPPN Frei Caneca has the highest richness of ferns and lycophytes, the seedless vascular plant groups, ever recorded to a NAF (138 spp.) (Lopes 2003). Here, we present the inventory of the ferns and lycophytes flora of the RPPN Pedra D'Antas, where a first record of Serpocaulon hirsutulum for the northeastern Brazil is reported and the status of the Serra do Urubu as a hotspot for ferns diversity in NAF is confirmed.

\section{Material and Methods}

\section{Study area}

The RPPN Pedra D'Antas (8'42'14"S - 35'51'10"'W, max. alt.: $800 \mathrm{~m})$ is located in Lagoa dos Gatos (47.25\% of the area), Jaqueira (6.72\%) and São Benedito do Sul (46.03\%) municipalities of the State of Pernambuco, northeastern Brazil. The area presents approximately 325 hectares of Open Ombrophylous Atlantic Forest in diverse stages of preservation (Figure 1). The relief of the area is hilly with flat tops, steep slopes and narrow valleys. The area has predominantly sandy-clay, yellowish red argisol soil (IBGE 1995). There are several perennial water bodies of the Una River Basin (CPRM 2005). The local climate is tropical moist as with hot and dry summer and rainy winter, according to Koppen classification (1948). The average annual rainfall is approximately $1,345 \mathrm{~mm}$. The annual average temperature is $23.6^{\circ} \mathrm{C}$, ranging from $18^{\circ} \mathrm{C}$ to $30^{\circ} \mathrm{C}(\mathrm{CPRM} 2005)$.

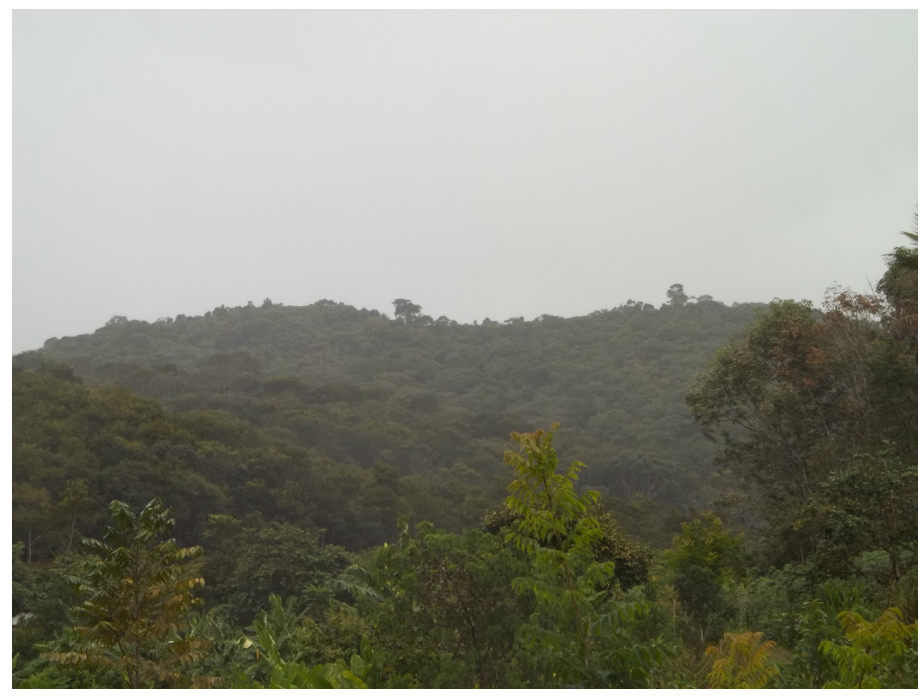

Figure 1. Part of the RPPN Pedra D'Antas, a remnant of Open Ombrophilous Atlantic Forest, situated in state of Pernambuco, northeastern Brazil.

\section{Inventory}

Fifteen trips were carried out from October/2011 to January/2013 to the study area. On each trip, the forest fragment was explored through systematic walks, georeferencing points with GPS and giving priority to the preferential environments for establishment of ferns and lycophytes (e.g. forest edge and interior, areas near streams and other water bodies, ravines, valleys and slopes and rocky areas). Besides the systematic exploration of these environments, random walks were also conducted to cover the most of the forest fragment area. Collection and herborization of specimens followed the usual techniques for vascular plants (Mori et al. 1989). Voucher specimens were incorporated into the UFP herbarium collection. Identification was carried out with aid of specialized bibliography, consultation with specialists and comparison with herborized material from the UFP herbarium determined by specialists. The classification presented follows the Pteridophyte Phylogeny Group (PPG 2016). The names of the authors of the species were abbreviated according to the Flora do Brasil (2020).

Field notes at the collection site of specimens were taken, ranking the species in the following categories: terrestrial, rupicolous, hemiepiphyte and holoepiphyte (Salvo Garcia \& Verdugo 1990). For comparison of species richness in the study area with other areas, we consulted the available inventories in the NAF. Comments about some taxa (distribution and taxonomic characteristics) were based on cited literature.

\section{Results and Discussion}

Seventy-four species of ferns (Polypodiospsida Class), representing 46 genera and 17 families were recorded in the RPPN Pedra D'Antas (Table 1). As for lycophytes (Lycopodiopsida Class), four species in two families and two genera were recorded (Table 1). The fern and lycophyte richness of the study area ( $79 \mathrm{spp}$.) can be considered high when contrasted to other NAF areas (Table 2). This number of species represents about 36\% of the richness of ferns and lycophytes estimated for the state of Pernambuco (214 spp.) according to Prado et al. (2015). This emphasizes the relevance of preserving the area for the conservation of the studied groups.

The most representative families were Pteridaceae (17 species), Polypodiaceae (14 spp.), Dryopteridaceae (nine spp.) and Thelypteridaceae (seven spp.). These families account for approximately $64 \%$ of the sampled ferns. Among the sampled families, $26 \%$ are represented by only one species. The genus Adiantum L. presented the highest specific representativeness, nine species (Table 1).

The fern and lycophyte flora of the present area is mostly composed of species common to other NAF inventoried areas (e.g. Santiago \& Barros 2003, Xavier \& Barros 2003, Santiago et al. 2004, Xavier \& Barros 2005, Pietrobom \& Barros 2006, Pereira et al. 2011, Pereira et al. 2013). However, some taxa are not usually registered in NAF, such as Megalastrum umbrinum (Farias et al. 2015), which has been found only in the present area, as well Elaphoglossum glabellum and Ctenitis glandulosa, which had few records in this unit and were previously recorded in two other NAF areas.

In addition, Serpocaulon hirsutulum was found, representing a new record for the Northeast of Brazil. The species S. hirsutulum (see characteristics in Schwartsburd \& Smith 2013) has distribution restricted to the states of Minas Gerais, São Paulo (southeast) and Pernambuco (northeast). In the latter, it is recorded in two areas (i.e. Serra do Urubu): the RPPN Frei Caneca (recently determined and unpublished material) and the present studied area.

Only one exotic species was recorded in the RPPN Pedra D'Antas: Macrothelypteris torresiana. This species is native from Madagascar, Japan, Indonesia, Thailand, Malaysia, Queenslândia (Robinson et al., 2010), and it is widely naturalized and often collected in Brazilian forests, particularly in the areas of the Atlantic Forest and Cerrado, according to Salino \& Almeida (2015). 
As for the types of habitat, terrestrial species (55\%) were predominant. This result supports the majority of fern and lycophyte inventories in the NAF (e.g. Santiago \& Barros 2003, Xavier \& Barros 2003, Santiago et al. 2004, Xavier \& Barros 2005, Pietrobom \& Barros 2006, Pereira et al. 2011, Pereira et al. 2013). This pattern of predominance of terrestrial habitat can be explained by the diversity of favorable conditions promoted by this substrate, such as water availability, shade, as well as greater availability of nutrients (Sota 1971).

The high richness recorded here for the RPPN Pedra D'Antas and reported by Lopes (2003) for the RPPN Frei Caneca supports the concept this area as a hotspot for the fern and lycophyte diversity in the NAF. As a consequence, the importance of effective protection of the area is reinforced.

Table 1. Ferns (Polypodiopsida) and Lycophytes (Lycopodiopsida) recorded in Conservation Unit of the Northeastern Atlantic Forest - RPPN Pedra D'Antas, Pernambuco, Brazil, between October/2011 and January/2013.

\begin{tabular}{|c|c|c|c|c|}
\hline \multirow{2}{*}{\multicolumn{5}{|c|}{$\begin{array}{l}\text { Class/Family } \\
\text { POLYPODIOPSIDA }\end{array}$}} \\
\hline & & & & \\
\hline \multirow[t]{2}{*}{ Anemiaceae } & Anemia hirta (L.) Sw. & Rupicolous & UFP 81.287 & R.P. Farias 121 \\
\hline & Anemia villosa Humb. \& Bonpl. ex Willd. & Rupicolous & UFP 81.285 & R.P. Farias 134 \\
\hline \multirow[t]{4}{*}{ Aspleniaceae } & Asplenium auritum $\mathrm{Sw}$. & Holocorticicolous & UFP 81.278 & R.P. Farias 90 \\
\hline & Asplenium formosum Willd. & Rupicolous / Holocorticicolous & UFP 81.279 & R.P. Farias 115 \\
\hline & Asplenium salicifolium $\mathrm{L}$. & Rupicolous & UFP 81.280 & R.P. Farias 141 \\
\hline & Asplenium serratum L. & Rupicolous / Holocorticicolous & UFP 81.281 & R.P. Farias 101 \\
\hline \multirow[t]{4}{*}{ Blechnaceae } & Neoblechnum brasiliense (Desv.) Gasper \& V.A.O. Dittrich & Terricolous & UFP 81.338 & R.P. Farias 100 \\
\hline & Blechnum occidentale L. & Terricolous & UFP 81.337 & R.P. Farias 107 \\
\hline & $\begin{array}{l}\text { Telmatoblechnum serrulatum (Rich.) Perrie, D.J. Ohlsen \& } \\
\text { Brownsey }\end{array}$ & Terricolous & UFP 81.336 & R.P. Farias 120 \\
\hline & Salpichlaena volubilis (Kaulf.) J.Sm. & Hemicorticicolous & UFP 81.340 & R.P. Farias 110 \\
\hline \multirow[t]{3}{*}{ Cyatheaceae } & Cyathea abreviata I.Fern. & Terricolous & UFP 81.371 & R.P. Farias 25 \\
\hline & Cyathea microdonta (Desv.) Domin & Terricolous & UFP 81.372 & R.P. Farias 181 \\
\hline & Cyathea praecincta (Kunze) Domin & Terricolous & UFP 81.363 & R.P. Farias 125 \\
\hline Dennstaedtiaceae & Pteridium arachnoideum (Kaulf.) Maxon & Terricolous & UFP 81.320 & R.P. Farias 168 \\
\hline \multirow[t]{9}{*}{ Dryopteridaceae } & Ctenitis distans (Brack.) Ching & Terricolous & UFP 81.117 & R.P. Farias 155 \\
\hline & Ctenitis glandulosa R.S. Viveiros \& Salino & Terricolous & UFP 81.119 & R.P. Farias 157 \\
\hline & Cyclodium heterodon (Schrad.) T. Moore & Terricolous & UFP 81.317 & R.P. Farias 34 \\
\hline & Cyclodium meniscioides (Willd.) C. Presl & Terricolous & UFP 81.341 & R.P. Farias 94 \\
\hline & Elaphoglossum glabellum J. Sm. & Holocorticicolous & UFP 81.370 & R.P. Farias 119 \\
\hline & Megalastrum umbrinum (C. Chr.) A.R. Sm \& R.C. Moran & Terricolous & UFP 75.754 & R.P. Farias 15 \\
\hline & Mickelia guianensis (Aubl.) R.C Moran, Sundue \& Labiak & Hemicorticicolous & UFP 81.345 & R.P. Farias 79 \\
\hline & Olfersia cervina (L.) Kunze & Terricolous & UFP 81.352 & R.P. Farias 127 \\
\hline & Polybotrya osmundaceae Willd. & Hemicorticicolous & UFP 81.343 & R.P. Farias 77 \\
\hline Gleicheniaceae & Gleichenellla pectinata (Willd.) Ching & Terricolous & UFP 81.369 & R.P. Farias 88 \\
\hline \multirow[t]{3}{*}{ Hymenophyllaceae } & Didymoglossum hymenoides (Hedw.) Copel. & Rupicolous / Holocorticicolous & UFP 81.311 & R.P. Farias 140 \\
\hline & Didymoglossum krausii (Hook. \& Grev.) C. Presl & Rupicolous / Holocorticicolous & UFP 81.312 & R.P. Farias 136 \\
\hline & Hymenophyllum polyanthos (Sw.) Sw. & Holocorticicolous & UFP 81.316 & R.P. Farias 139 \\
\hline Lindsaeaceae & Lindsaea lancea (L.) Bedd. & Terricolous & UFP 81.342 & R.P. Farias 83 \\
\hline \multirow[t]{2}{*}{ Lomariopsidaceae } & Lomariopsis japurensis (Mart.) J. Sm. & Hemicorticicolous & UFP 81.353 & R.P. Farias 81 \\
\hline & Nephrolepis biserrata (Sw.) Schott & Rupicolous & UFP 81.354 & R.P. Farias 126 \\
\hline \multirow[t]{2}{*}{ Lygodiaceae } & Lygodium venustum $\mathrm{Sw}$. & Terricolous & UFP 81.277 & R.P. Farias 122 \\
\hline & Lygodium volubile Sw. & Terricolous & UFP 81.276 & R.P. Farias 114 \\
\hline Marattiaceae & Danaea geniculata Raddi & Terricolous & UFP 81.308 & R.P. Farias 129 \\
\hline \multirow[t]{14}{*}{ Polypodiaceae } & Campyloneurum nitidum (Kaulf.) C. Presl & Rupicolous / Holocorticicolous & UFP 81.335 & R.P. Farias 149 \\
\hline & Campyloneurum repens (Aubl.) C. Presl & Rupicolous / Holocorticicolous & UFP 81.355 & R.P. Farias 82 \\
\hline & Pleopeltis desvauxii (Klotzsch) Salino & Rupicolous / Holocorticicolous & UFP 81.328 & R.P. Farias 164 \\
\hline & Microgramma vacciniifolia (Langsd. \& Fisch.) Copel. & Holocorticicolous & UFP 81.349 & R.P. Farias 78 \\
\hline & Microgramma lycopodioides (L.) Copel & Holocorticicolous & UFP 81.346 & R.P. Farias 72 \\
\hline & Pecluma pilosa (A.M. Evans) M. Kessler \& A.R. Sm. & Holocorticicolous & UFP 81.333 & R.P. Farias 178 \\
\hline & Phlebodium pseudoaureum (Cav.) Lellinger & Holocorticicolous & UFP 81.331 & R.P. Farias 144 \\
\hline & Phlebodium decumanum (Willd.) J. Sm. & Holocorticicolous & UFP 81.332 & R.P. Farias 143 \\
\hline & Pleopeltis astrolepis (Liebm.) E. Fourn. & Rupicolous / Holocorticicolous & UFP 81.358 & R.P. Farias 95 \\
\hline & Pleopeltis furcata (L.) A.R. Sm. & Holocorticicolous & UFP 81.351 & R.P. Farias 68 \\
\hline & Pleopeltis hirsutissima (Raddi) de la Sota & Rupicolous / Holocorticicolous & UFP 81.366 & R.P. Farias 62 \\
\hline & Polypodium dulce Poir. & Rupicolous / Holocorticicolous & UFP 81.303 & R.P. Farias 153 \\
\hline & Serpocaulon catharinae (Langsd. \& Fisch.) A.R. Sm. & Holocorticicolous & UFP 81.305 & R.P. Farias 151 \\
\hline & Serpocaulon hirsutulum (T. Moore) Schwartsb. \& A.R. Sm & Terricolous & UFP 81.302 & R.P. Farias 150 \\
\hline
\end{tabular}

*Specimens with sterile material 
Table 1. Continued..

\begin{tabular}{|c|c|c|c|c|}
\hline Class/Family & $\begin{array}{r}\text { Species } \\
\end{array}$ & Habitats & Voucher Number & Collector Number \\
\hline \multirow[t]{17}{*}{ Pteridaceae } & Adiantopsis radiata (L.) Fée & Terricolous & UFP 81.244 & R.P. Farias 105 \\
\hline & Adiantum abscissum Schrad. & Terricolous & UFP 81.245 & R.P. Farias 54 \\
\hline & Adiantum dolosum Kunze & Terricolous & UFP 81.247 & R.P. Farias 48 \\
\hline & Adiantum glaucescens Klotzsch & Terricolous & UFP 81.250 & R.P. Farias 52 \\
\hline & Adiantum latifolium Lam. & Terricolous & UFP 81.252 & R.P. Farias 43 \\
\hline & Adiantum obliquum Willd. & Terricolous & UFP 81.258 & R.P. Farias 47 \\
\hline & Adiantum pulverulentum $\mathrm{L}$. & Terricolous & UFP 81.259 & R.P. Farias 50 \\
\hline & Adiantum terminatum Kunze ex Miq. & Terricolous & UFP 81.261 & R.P. Farias 44 \\
\hline & Adiantum tetraphyllum Willd. & Terricolous & UFP 81.263 & R.P. Farias 55 \\
\hline & Ananthacorus angustifolius (Sw.) Underw. \& Maxon & Rupicolous & UFP 81.275 & R.P. Farias 61 \\
\hline & Doryopteris sagittifolia J. Sm. & Rupicolous & UFP 81.270 & R.P. Farias 97 \\
\hline & Doryopteris varians $\mathrm{Sm}$. & Rupicolous & UFP 81.269 & R.P. Farias 75 \\
\hline & Hemionitis palmata $\mathrm{L}$. & Rupicolous & UFP 81.274 & R.P. Farias 102 \\
\hline & Hemionitis tomentosa (Lam.) Raddi & Rupicolous & UFP 81.272 & R.P. Farias 106 \\
\hline & Pityrogramma calomelanos (L.) Link & Terricolous & UFP 81.268 & R.P. Farias 113 \\
\hline & Vittaria graminifolia Kaulf. & Holocorticícola & UFP 81.267 & R.P. Farias 93 \\
\hline & Vittaria lineata (L.) Sm. & Rupicolous / Holocorticicolous & UFP 81.266 & R.P. Farias 111 \\
\hline Saccolomataceae & Saccoloma elegans Kaulf.* & Terricolous & & \\
\hline \multirow[t]{2}{*}{ Tectariaceae } & Triplophyllum dicksonioides (Fée) Holttum & Terricolous & UFP 81.307 & R.P. Farias 86 \\
\hline & Triplophyllum hirsutum (Holttum) J. Prado \& R.C Moran & Terricolous & UFP 81.306 & R.P. Farias 84 \\
\hline \multirow[t]{7}{*}{ Thelypteridaceae } & Christellla hispidula (Decne.) Holttum & Terricolous & UFP 81.321 & R.P. Farias 174 \\
\hline & Cyclosorus interruptus (Willd.) H. Itô & Terricolous & UFP 81.360 & R.P. Farias 132 \\
\hline & Goniopteris jamesonii (Hook.) Salino \& T.E. Almeida & Terricolous & UFP 81.327 & R.P Farias 177 \\
\hline & Macrothelypteris torresiana (Gaudich.) Ching* & Terricolous & & \\
\hline & Meniscium macrophyllum Kunze & Terricolous & UFP 81.326 & R.P. Farias 142 \\
\hline & Meniscium serratum Cav. & Terricolous & UFP 81.359 & R.P. Farias 131 \\
\hline & Steiropteris polypodioides (Raddi) Salino \& T.E. Almeida & Terricolous & UFP 81.323 & R.P. Farias 170 \\
\hline \multicolumn{5}{|c|}{ LYCOPODIOSPSIDA } \\
\hline Lycopodiaceae & Palhinhaea cernua (L.) Vasc. \& Franco & Terricolous & UFP 81.310 & R.P. Farias 73 \\
\hline \multirow[t]{3}{*}{ Selaginellaceae } & Selaginella muscosa Spring & Terricolous & UFP 81.121 & R.P. Farias 159 \\
\hline & Selaginella producta Baker & Terricolous & UFP 81.120 & R.P. Farias 158 \\
\hline & Selaginella sulcata (Desv. ex. Poir.) Spring ex Mart. & Terricolous & UFP 81.122 & R.P. Farias 160 \\
\hline
\end{tabular}

*Specimens with sterile material.

Table 2. Ten inventories of Ferns (Polypodiopsida) and Lycophytes (Lycopodiopsida) performed Northeastern Atlantic Forest with greatest number of species recorded.

\begin{tabular}{ccc}
\hline Inventories & Study Site/State & Number of species \\
\hline Lopes (2003) & RPPN Frei Caneca/Pernambuco & 138 \\
Pereira et al. (2013) & ESEC Murici/Alagoas & 107 \\
Santiago et al. (2004) & Bonito/Pernambuco & 91 \\
Pietrobom \& Barros (2003) & Mata do Estado/Pernambuco & 90 \\
Barros et al. (2006) & Serra Grande Mill/Alagoas & 85 \\
Pietrobom \& Barros (2007) & Água Azul Mill/Pernambuco & 83 \\
This Study & RPPN Pedra D'Antas/Pernambuco & 79 \\
Pereira et al. (2007) & Gurjaú Ecological Forest/Pernambuco & 75 \\
Pietrobom \& Barros (2006) & Maria Maior Forest/Alagoas & 72 \\
Xavier \& Barros (2005) & João Vasconcelos Sobrinho Ecological Park/Pernambuco & 66 \\
\hline
\end{tabular}

\section{Acknowledgments}

The authors thank Dr. Jefferson Prado for the identification of several specimens, as well as Dra ${ }^{\mathrm{a}}$. Regina Hirai; Dr. Luiz Armando de Araújo Goés-Neto for identifying species of Selaginellaceae family; Dr. Alexandre Salino and $\mathrm{Dr}^{\mathrm{a}}$. Raquel Viveros for identifying Ctenitis species. We are also grateful the reviewers for comments on the manuscript.

\section{Author's Contribution}

Rafael de Paiva Farias: Contribution to data collection, contribution to data analysis and interpretation, contribution to manuscript preparation and contribution to critical revision, adding intellectual content.
Ivo Abraão Araújo da Silva: Contribution to data collection, contribution to data analysis and interpretation, contribution to manuscript preparation and contribution to critical revision, adding intellectual content.

Anna Flora de Novaes Pereira: contribution to data analysis and interpretation, contribution to manuscript preparation.

Augusto César Pêssoa Santiago: contribution to data analysis and interpretation, contribution to manuscript preparation.

Iva Carneiro Leão Barros: Contribution to critical revision, adding intellectual content.

\section{Conflicts of interest}

The authors declare that they have no conflict of interest related to the publication of this manuscript. 


\section{References}

BARROS, I.C.L., SANTIAGO, A.C.P., PEREIRA, A.F.N. \& PIETROBOM, M.R. 2006. Pteridófitas. In Diversidade Biológica e Conservação da Floresta Attântica ao Norte do Rio São Francisco (K. Pôrto, J. Almeida-Cortez \& M. Tabarelli, orgs.). Ministério do Meio Ambiente, Brasília, p.147-171.

FORZZA, R.C., et al. 2010. Catalogue of the Plants and Fungi of Brazil.

CPRM - Companhia de Pesquisa de Recursos Minerais Serviço Geológico do Brasil. 2005. Diagnóstico do município de Lagoa dos Gatos, Pernambuco. (last access at 24/08/2016)

FARIAS, R.P., SANTIAGO, A.C.P., PEREIRA, A.F.N., SILVA, I.A.A. \& BARROS, I.C.L. 2015. New records of Megalastrum in the northeastern Atlantic Forest. Check List 11(2): 1-3.

FLORA DO BRASIL. 2020. http://floradobrasil.jbrj.gov.br/reflora/floradobrasil/ FB128483. (last access at 12/08/2017).

GASPER, A.L., SALINO, A., VIBRANS, A.C., SEVEGNANI, L., VERDI, M., KORTE, A., SANTOS, A.S., DREVECK, S., CADORIN, T.J., SCHMITT, J.L. \& CAGLION, E. 2012. Pteridófitas de Santa Catarina: um olhar sobre os dados do Inventário Florístico Florestal de Santa Catarina, Brasil. Acta Bot. Bras. 26(2): 421-434.

IBGE - INSTITUTO BRASILEIRO DE GEOGRAFIA E ESTATÍSTICA. 1985. Atlas Nacional do Brasil: Região Nordeste. Relatório Técnico. IBGE, Rio de Janeiro.

KÖPPEN, W. 1948. Climatologia. Fondo de Cultura Económica, México

MAGURRAN, A.E. 2004. Measuring biological diversity. Blackwell, London.

MELO, A., AMORIM, B.S., PESSOA, E., MACIEL, J.R. \& ALVES, M. 2016. Serra do Urubu, a biodiversity hot-spot for angiosperms in the northern Atlantic Forest (Pernambuco, Brazil). Check List 12(1): 1-25.

MORI, S.A., SILVA, L.A.M. \& LISBOA, G. 1989. Manual de manejo do herbário fanerogâmico. Centro de Pesquisa do Cacau, Ilhéus.

PEREIRA, A.F.N., BARROS, I.C.L., SANTIAGO, A.C.P. \& SILVA, I.A.A. 2011. Florística e distribuição geográfica das samambaias e licófitas da Reserva Ecológica de Gurjaú, Pernambuco, Brasil. Rodriguésia 62(1): 1-10.

PEREIRA, A.F.N., BARROS, I.C.L., XAVIER, S.R.S. \& SANTIAGO, A.C.P. 2007. Composição florística e ecologia da pteridoflora de fragmentos de Floresta Atlântica (Reserva Ecológica de Gurjaú, Cabo de Santo Agostinho, Pernambuco, Brasil). Revista Brasileira de Biociências 5(2): 489-491.

PEREIRA, A.F.N., SILVA, I.A.A., SANTIAGO, A.C.P. \& BARROS, I.C.L. 2013. Richness, geographic distribution and ecological aspects of the fern community within the Murici Ecological Station in the state of Alagoas, Brazil. Acta Bot. Bras. 27(4): 788-800.

PIETROBOM, M.R. \& BARROS, I.C.L. 2003b. Pteridófitas de um fragmento florestal na Serra do Mascarenhas, estado de Pernambuco, Brasil. Insula 32: 73-118

PIETROBOM, M.R. \& BARROS, I.C.L. 2006. Associações entre as espécies de pteridófitas em dois fragmentos de Floresta Atlântica do Nordeste brasileiro. Biotemas 19(3): 15-26.

PIETROBOM, M.R. \& BARROS, I.C.L. 2007. Pteridoflora do Engenho Água Azul, município de Timbaúba, Pernambuco, Brasil. Rodriguésia 58(1): 85-94

PPG 1 - The Pteridophyte Phylogeny Group. 2016. A community-derived classification for extant lycophytes and ferns. J. Syst. Evo. 54(6): 563-603.
PRADO, J. \& HIRAI, R.Y. 2011. Checklist das licófitas e samambaias do Estado de São Paulo, Brasil. Biota Neotrop. 11(1a): 161-190. http://dx.doi.org/10.1590/ S1676-06032011000500012 (last access at 20/01/2017).

PRADO, J., SYLVESTRE, L.S., LABIAK, P.H., WINDISCH, P.G., SALINO, A., BARROS, I.C.L., HIRAI, R.Y., ALMEIDA, T.E., SANTIAGO, A.C.P., KIELING-RUBIO, M.A., PEREIRA, A.F.N., ØLLGAARD, B., RAMOS, C.G.V., MICKEL, J.T., DITTRICH, V.A.O., MYNSSEN, C.M., SCHWARTSBURD, P.B., CONDACK, J.P.S., PEREIRA, J.B.S. \& MATOS, F.B. 2015. Diversity of ferns and lycophytes in Brazil. Rodriguésia 66(4): 1073-1083.

RIBEIRO, M.C., METZGER, J.P., MARTENSEN, A.C., PONZONI, F.J. \& HIROTA, M.M. 2009. The Brazilian Atlantic Forest: How much is left, and how is the remaining forest distributed? Implications for conservation. Biological Conservation 142(6): 1141-1153.

ROBINSON, R.C., SHEFFIELD, E. \& SHARPE, J.M. 2010. Problem fern: their impact and management. In Fern Ecology (K. Mehltreter, L.R. Walker \& J.M. Sharpe, eds.). Cambridge University Press, New York, p.255-322.

SALINO, A. \& ALMEIDA, T.E. 2015. Thelypteridaceae in Lista de Espécies da Flora do Brasil. Jardim Botânico do Rio de Janeiro.

SALVO, A.E. \& GARCIA-VERDUGO, J.C. 1990. Biogeografia numerica en pteridologia. In Taxonomia, biogeografia y conservación de pteridófitos (J. Rita, ed.). Sociedad Historia Natural Baleares-IME, Palma de Mallorea, p.115-150.

SANTIAGO, A.C.P. \& BARROS, I.C.L. 2003. Pteridoflora do Refúgio Ecológico Charles Darwin (Igarassu, Pernambuco, Brasil). Acta Bot. Bras. 17(4): 597-604.

SANTIAGO, A.C.P., BARROS, I.C.L. \& SYLVESTRE, L.S. 2004. Pteridófitas ocorrentes em três fragmentos florestais de um brejo de altitude (BonitoPernambuco-Brasil). Acta Bot. Bras. 18(4): 781-792.

SAVE BRASIL. http://www.savebrasil.org.br/ last access at (21/12/2016).

SCHWARTSBURD, P.B \& SMITH, A. 2013. Novelties in Serpocaulon (Polypodiaceae). Bot. Res. Inst. Texas 7(1): 85-93.

SOTA, E.R. 1971. El epifitismo y las pteridofitas en Costa Rica (America Central). Nova Hedwigia 21(2-4): 401-465.

TABARELLI, M., SIQUEIRA FILHO, J. A. \& SANTOS, A. M. M. 2006. A Floresta Atlântica ao norte do rio São Francisco. In Diversidade Biológica e Conservação da Floresta Atlântica ao Norte do Rio São Francisco (K. Pôrto, J. AlmeidaCortez \& M. Tabarelli, Orgs). Ministério do Meio Ambiente, Brasília, p.25-40.

XAVIER, S.R.S. \& BARROS, I.C.L. 2003. Pteridófitas ocorrentes em fragmentos de floresta serrana no estado de Pernambuco, Brasil. Rodriguésia 54(83): 13-21.

XAVIER, S.R.S. \& BARROS, I.C.L. 2005. Pteridoflora e seus aspectos ecológicos ocorrentes no Parque Ecológico João Vasconcelos Sobrinho, Caruaru, PE, Brasil. Acta Bot. Bras. 19(4): 775-781. 